\title{
OBSERVATIONS ON A COLLAPSING KAME TERRAGE IN GLACIER BAY NATIONAL MONUMENT, SOUTH-EASTERN ALASKA*
}

\author{
By Garry D. MaKenzie \\ (Institute of Polar Studies, Ohio State University, Columbus, Ohio 432 I o, U.S.A.)
}

\begin{abstract}
Detailed observations on a collapsing kame terrace indicate that the terrace is being reshaped by: slumping and sliding of debris into depressions, melt-water erosion on the side of the terrace, debris flows in the gullies, and stagnant-ice bursts, a phenomenon analogous to a glacier burst except in the mode of formation of the water. Temperatures in the gravel over the ice, where the gravel is about $4 \mathrm{~m}$ thick, indicate that the rate of melting of the upper surface of the ice due to conduction may be as high as $24 \mathrm{~cm}_{\text {year }}^{-1}$. Highest temperatures in the gravel were recorded during periods of heavy rainfall.
\end{abstract}

RÉsumé. Observations sur une terrasse affaissée dans le Glacier Bay National Monument, sud-est Alaska. Des observations détaillées sur une terrasse affaissée d'un "Kame" indiquent que la terrasse est reformée par: effondrement et glissement de débris dans des dépressions, érosion par l'eau de fonte du bord de la terrasse, débris coulant dans les ravins et résurgence d'eau de fonte de la glace stagnante, phénomène analogue à celle des glaciers sauf dans le mode de formation de l'eau. Les températures dans les débris au-dessus de la glace où ils atteignent $4 \mathrm{~m}$ d'épaisseur, indiquent que la vitesse de fonte de la surface supérieure de la glace due à la conduction thermique, peut atteindre jusqu'à $24 \mathrm{~cm}$ par an. Les plus hautes températures dans les débris furent enregistrées durant les périodes de fortes pluies.

Zujammenfassung. Beobachtungen an einer zerfallenden Kames-Terrasse im Glacier Bay National Monument, Südost-Alaska. Eingehende Beobachtungen an einer zerfallenden Kames-Terrasse zeigen, dass die Terrasse umgeformt wird durch: Stürzen und Gleiten von Schutt in Vertiefungen, Schmelzwassererosion an der Terrassenflanke, Schuttfluss in die Gräben und Ausbrüche stagnierten Eises, eine Erscheinung analog einem Gletscherausbruch bis auf die Art der Bildung von Wasser. Temperaturen im Schutt über dem Eis zeigen bei einer Schuttmächtigkeit von etwa $4 \mathrm{~m}$, dass die Abschmelzung durch Wärmeleitung an der Eisoberfläche bis zu $24 \mathrm{~cm}$ pro Jahr betragen kann. Die höchsten Temperaturen im Schutt wurden in Perioden heftigen

\section{INTRODUCTION}

During the r 966 and 1967 summer field seasons, the writer made observations on a collapsing kame terrace in Adams Inlet, Glacier Bay National Monument, Alaska (Fig. I). From these observations the mechanisms and rate of collapse of the ice-cored kame terrace were determined.

The mechanisms of formation of kames, eskers and other ice-contact deposits have been summarized by Charlesworth (1957), Flint ([1957]) and Embleton and King (1968). Field observations (Sharp, I947, I949; Clayton, I964) on the arrangement of supraglacial deposits have helped to clarify problems associated with ice-contact deposits existing in areas long since deglaciated. Generally, it is concluded that an irregularly distributed surface cover promotes differential ablation, forming a hummocky surface. Movement of debris from mounds or kames into depressions, followed by a change in the ablation rate on the mounds and in the depressions, results in an inversion of the topography.

Observations have been made on the rate of collapse of ice-cored deposits and the various factors affecting this rate. Sharp (1949, p. 298) noted that Philipp had observed as early as I9I2 that a thin mantle of debris promoted ablation. Lister (r953) made a quantitative study of the rate of melting of debris-covered ice and found that in the Icelandic climate a debris cover of 4-7 mm was required to provide protection to the ice. Thinner debris covers increased the ablation rate. The grain-size of the debris was observed by Sharp (1949) to be an important factor in the ablation rate with a fine grain-size being a more effective insulator because fine-grained debris prevented the circulation of the air to a greater degree than coarse-grained material.

* Contribution No. 149, Institute of Polar Studies, Ohio State University, Columbus, Ohio, U.S.A. 
Swithinbank (1950), in a study of debris cones, concluded that the amount of heat transmitted to buried snow or ice depended on the thermal properties (conductivity and radiation absorption coefficient), and the mechanical and structural properties (thickness and grain-size) of the debris cover.

\section{Location and setting}

Adams Inlet (lat. $58^{\circ} 5^{2^{\prime}}$ N., long. $136^{\circ} 5^{0^{\prime}}$ W.) is $108 \mathrm{~km}$ north-west of Juneau, Alaska, and it occupies an area of $27 \mathrm{~km}^{2}$ (Fig. I). It is bordered by mountains ranging in elevation from I 200 to $2200 \mathrm{~m}$ on the east and south, and on the north and west by low hills and outwash plains. In $1890-92$, when the area was visited by Reid (1896), ice was at an elevation of $380 \mathrm{~m}$ in Adams Inlet, and between 1890 and 1940 the surface of Adams Inlet Glacier was

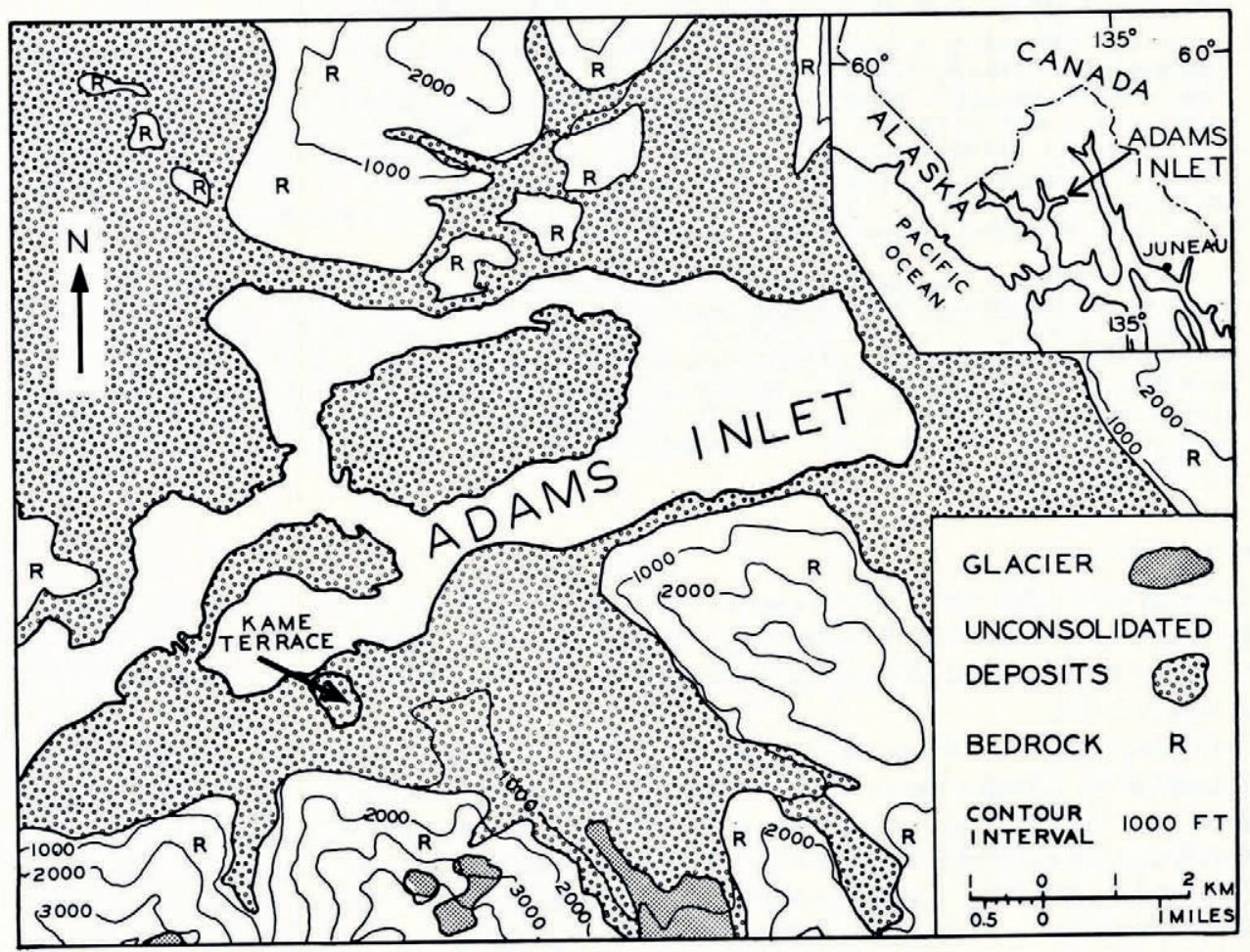

Fig. I. Location map showing the kame terrace on the south side of Adams Inlet. Adams Inlet (on inset map) is on the eastern side of Glacier Bay.

lowered by ablation at the rate of $7.9 \mathrm{~m} \mathrm{year}^{-1}$ (Field, 1947). During this period melt water from glaciers in tributary valleys and cirques deposited outwash against the sides of and over Adams Inlet Glacier. A remnant of this glacier, covered by debris deposited about i 930, was investigated in this study.

The deposit of gravel overlying stagnant ice occurs on the south side of Adams Inlet and is classified as a kame terrace (Fig. I). According to Flint ([1957], p. I49), a kame terrace is "... an accumulation of stratified drift laid down chiefly by streams between a glacier and an adjacent valley wall and left as a constructional terrace after disappearance of the glacier. ..." The deposit in question exhibits the terrace form only in those parts nearest the mountainside - the other parts, distal from the mountain, were originally deposited on ice and are collapsing 
because of the melting of this ice. The deposit in Adams Inlet is bounded on the north by alluvial fans; on the south, the undisturbed parts of the terrace abut other unconsolidated deposits. Gullies are being formed in the collapsing east and west slopes of the terrace. The elevation near the north edge of the terrace is about $60 \mathrm{~m}$. Only the outer collapsing part of the terrace was studied and mapped (Fig. 2).

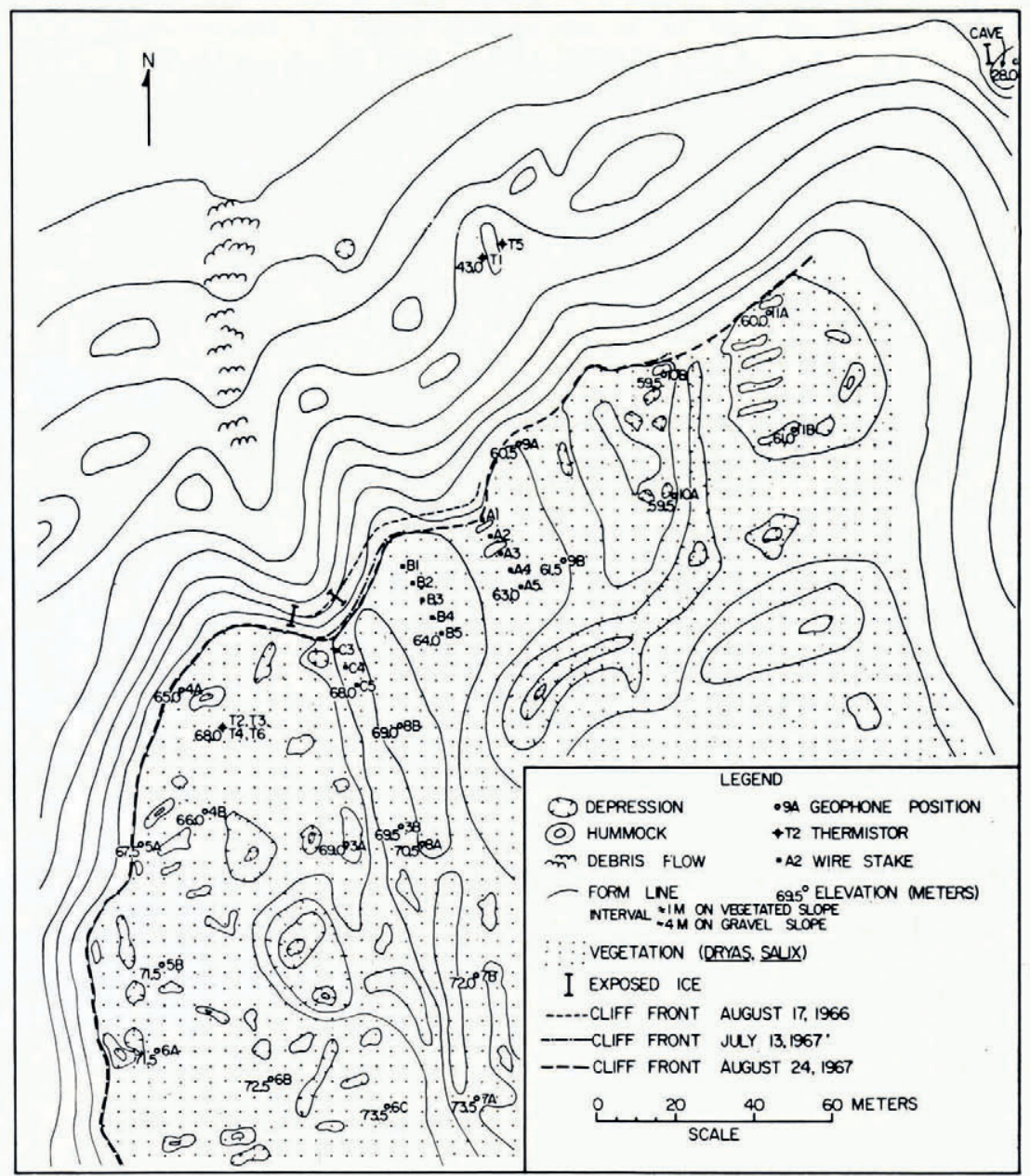

Fig. 2. Collapsing kame terrace on the south side of Adams Inlet. Elevation of vegetated surface is about $65 \mathrm{~m}$.

\section{Climate}

Most of Glacier Bay National Monument lies within Köppen's Dfc climatic types (cool snow-forest climate, moist in all seasons, with cool summers). January, the coolest month, probably has a mean temperature between $-3{ }^{\circ} \mathrm{C}$ and $-5{ }^{\circ} \mathrm{C}$ in the vicinity of Adams Inlet. The July average temperature for the two field seasons in Adams Inlet was $12.2^{\circ} \mathrm{C}$. The average precipitation for the same period was $0.24 \mathrm{~cm} \mathrm{~d}^{-1}$; the average for the latter part of June was lower and for August it was higher. In August i 966 there were 25 days with more than $0.025 \mathrm{~cm}$ of precipitation; the maximum precipitation in a $24 \mathrm{~h}$ period during that month was $5.49 \mathrm{~cm}$. 
Mean relative humidities were generally high. In July ig66 and i 967 they were 87 and $89 \%$, respectively. Winds were weak at observation times (07.00 and $21.00 \mathrm{~h}$ ) with speeds generally less than $0.8 \mathrm{~m} \mathrm{~s}^{-1}$.

Average cloudiness in tenths for the two summers, determined from the two observation times, was 8.7 for July and 8.5 for August.

No data are available on the date of the disappearance of the last snow from the ground or on the commencement of continuous winter snow cover for this area.

\section{Nature of the Debris Cover}

The ice beneath the collapsing deposit is covered with a sandy, coarse cobbly gravel with little remnant stratification. The gravel cover was first determined by seismic survey and

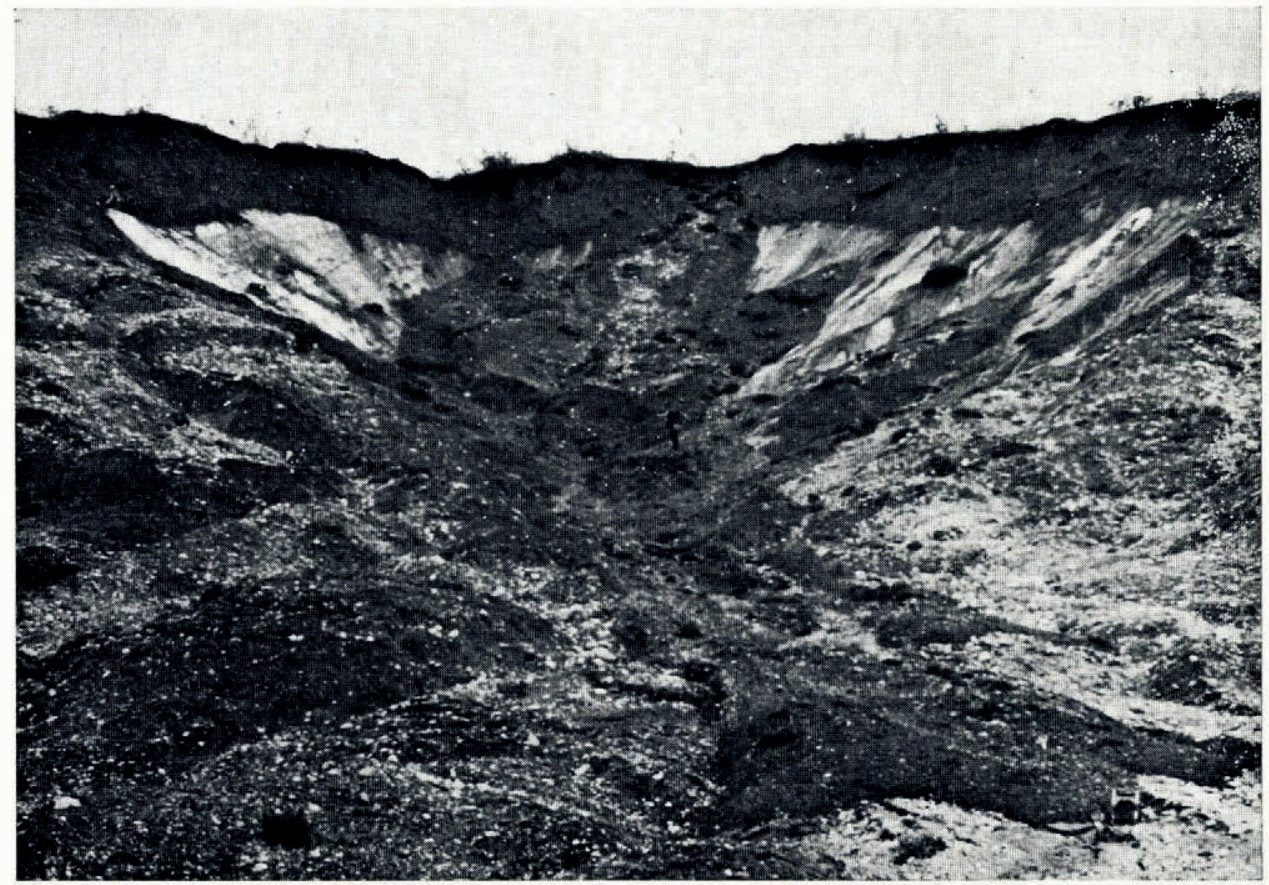

Fig. 3. North side of the kame terrace showing exposed stagnant ice. The gravel overlying the ice at the top of the terrace is about $3.5 \mathrm{~m}$ thick. Debris flow in gully is $0.6 \mathrm{~m}$ thick at the terminus.

ranges from 3 to $6 \mathrm{~m}$ in thickness with an average of about $4.2 \mathrm{~m}$. A $60 \mathrm{~m}$ long exposure of ice (Fig. 3) showed that the gravel cover near the edge of the terrace averaged $3.5 \mathrm{~m}$ in thickness. The surface of the kame terrace has a kame-and-kettle topography with depressions as deep as $5 \mathrm{~m}$. Most of the hummocks are less than $\mathrm{I} \mathrm{m}$ high and circular in outline with a basal diameter of approximately $2 \mathrm{~m}$, although some hummocks near the collapsing edge of the terrace are elongated ( 12 by $2 \mathrm{~m}$ ) parallel to the wasting slope (Fig. 2).

The surface vegetation is mainly Dryas with some alder and poplar (Fig. 4). This type of cover, a Dryas mat with scattered shrubs, is stage III of the plant succession established in Glacier Bay by Decker (Goldthwait and others, I966) and it indicates a time span of 20-25 years since the area became available for vegetation. This cover of vegetation and gravel has slowed the ablation of the underlying ice compared with the exposed glacier that occupied 
Adams Inlet until approximately 1950. Tilted shrubs and trees, and solifluction lobes, covered with Dryas indicate that the surface form of the terrace is constantly changing. At several spots on the kame terrace, hummocks show open patches of gravel where a recent change in the shape of the kame has resulted in an opening in the vegetation cover.

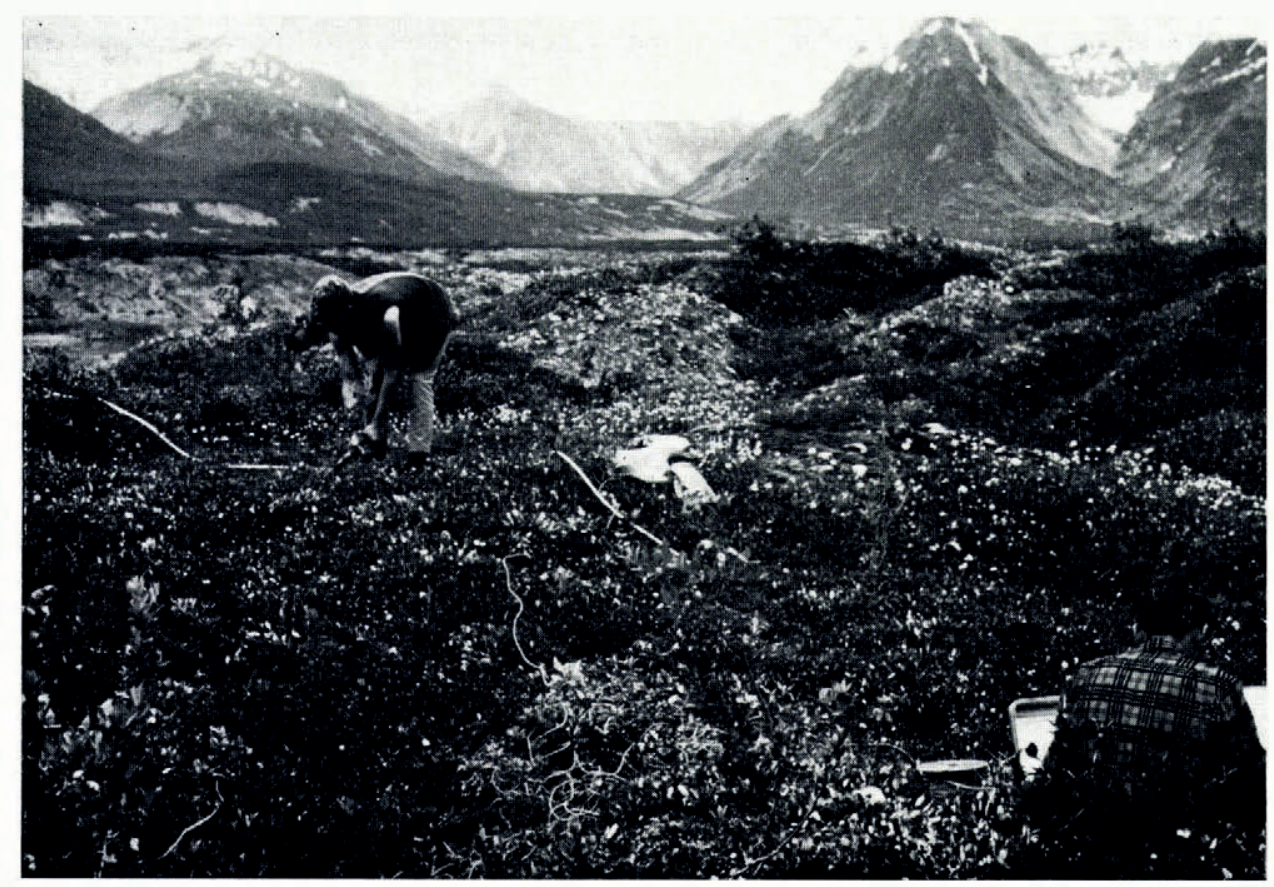

Fig. 4. Hummocky vegetated surface of kame terrace. Hammer seismograph is in operation to determine depth to stagnant ice. View is north-east.

\section{Nature of the Stagnant Ice}

The stagnant core was viewed in two places. One was a gully on the north side of the terrace where the gravel cover had slumped and slid from the face of the ice and flowed out as a debris flow (Figs. 2 and 3 ). The exposed thickness of ice here was about $5 \mathrm{~m}$, and the slope of this face was $39-40^{\circ}$. The other was the north-east corner of the terrace (cave in Figure 2), where the source of a spring was dug out to expose about $\mathrm{I} \mathrm{m}$ of the basal ice. At this locality, the only place where the base was seen, the ice rested on sand and silt with pebbles.

A conservative estimate of the thickness of ice remaining in the terrace in 1967 is $35 \mathrm{~m}$. The estimated width of the ice core is about $380 \mathrm{~m}$ and the length is about $400 \mathrm{~m}$. The surface of the ice, as seen in Figure 3, is slightly undulatory, at least near the outer parts of the terrace. Water was observed flowing from the ice-gravel interface, from fractures within the ice and from springs at the base of the ice. At the north-east corner of the terrace at the base of the ice, several 2 to $4 \mathrm{~cm}$ thick layers of silt with some sand and pebbles were found separated by $30-60 \mathrm{~cm}$ of ice. These layers may have been incorporated debris in or near the base of the former glacier.

Several ice crystals as long as $22 \mathrm{~cm}$ were found, indicating a relatively long period of stagnation. 


\section{Cave in stagnant ice}

At 09.55 h on I 3 August 1967 a large volume of water burst from beneath the north-east side of the kame terrace where a small spring had been found a month earlier. The outrush of water was audible from a distance of at least $1.5 \mathrm{~km}$. Two blocks of ice that apparently had been part of the stagnant ice mass were found on the alluvial fan adjacent to the kame terrace (Fig. 5). One of the blocks had dimensions of 2.2 by $\mathrm{I} .4$ by $0.8 \mathrm{~m}$ and was discovered $96 \mathrm{~m}$ from the cave; the other block, with dimensions 0.9 by 0.6 by $0.4 \mathrm{~m}$, was discovered about $100 \mathrm{~m}$ from the cave.

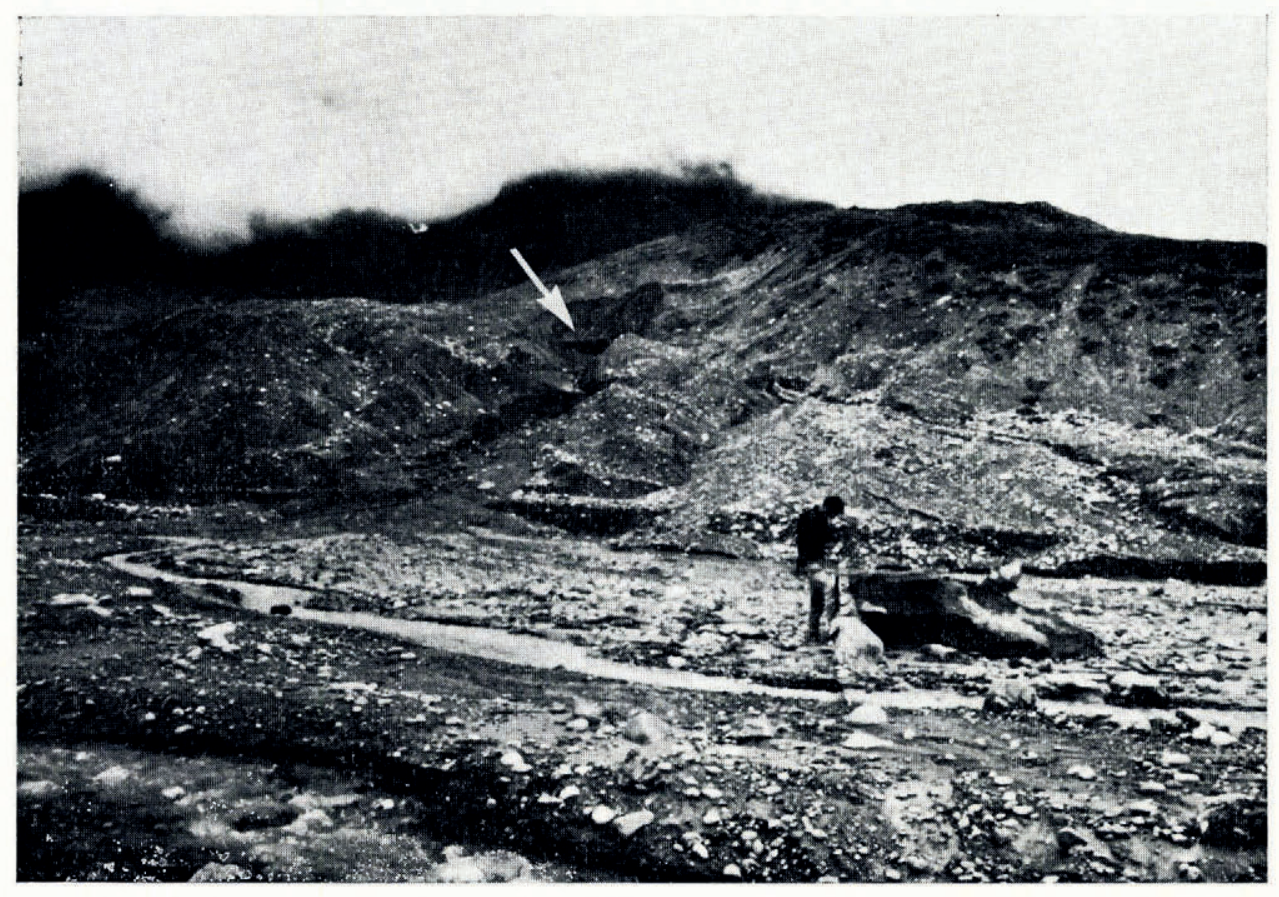

Fig. 5. North-east corner of the kame terrace showing the entrance to the stagnant-ice cave (arrow). A man is standing beside a large ice block expelled from the entrance to the cave.

The cave was visited less than Io $h$ after it had been opened and at that time it had an entrance $6 \mathrm{~m}$ wide and $2 \mathrm{~m}$ high. This width continued for several meters in from the entrance. At a distance of $26 \mathrm{~m}$ from the entrance the cave had narrowed to $\mathrm{I} \mathrm{m}$ across, and it extended for another $10 \mathrm{~m}$ at this diameter. The top of the entrance to the cave was rounded, and sand and water were flowing over the $35^{\circ}$ ice slope above the entrance. A stream occupied a $2 \mathrm{~m}$ wide channel in the unstable silt and clay floor. The roof of the cave consisted of debris-free ice with a scalloped surface. It is evident from its size that the cave had been formed before the release of water. Frozen silt at the side of the entrance to the cave, below the ice, and the slight flow of water that came from the spring at this location before the opening of the cave suggest that this part of the terrace at least was saturated with water. The cave apparently had been melted in the ice by the flow of rain and melt water through and beneath the ice. The impermeable silt and clay beneath the terrace also helped to hold the water in channels and fractures within the ice. Much of the terrace may have been saturated with water, because water was observed to flow over the surface of the large exposure of ice in the gully 
(Fig. 3). The pressure and quantity of water at the time of the outflow must have been considerable in order to move the ice blocks more than $90 \mathrm{~m}$ from the terrace. No water-level lines were seen on the walls of the cave and it was probably filled with water prior to the cave opening.

The sudden release of water with corresponding erosion and transport of debris and blocks of ice from buried stagnant ice is here termed a "stagnant-ice burst". This release of large volumes of water and accompanying erosion is, on a small scale, analogous to the glacier bursts or jökullhlaups that occur during a subglacial eruption of a volcano. In the case of the stagnant-ice burst, melt water and rain water are dammed by stagnant ice and an impermeable bed; the water is released when the pressure becomes too great or the ice dam is weakened by ablation. The stagnant-ice burst opens large areas in the ice to rapid ablation by warm air and thus speeds collapse of the ice-contact deposit.

\section{Mechanisms of Collapse}

As the ice melts beneath the gravel of the kame terrace, the gravel cover shifts and takes on a different topographic form. The fastest melting takes place where the ice is closest to the surface. This results in a mound or kame being formed where there is a thick cover of gravel, as the more rapidly melting ice around it subsides. The cover of gravel over the mound then slides, or moves as a lobe into the depression surrounding the kame. In this manner the terrace changes its shape and mixing of the previously stratified gravel occurs. In places where the terrace is completely underlain by ice all traces of the terrace form may be lost as the feature changes to an accumulation of kames. At this point the feature may more properly be termed a collapsed terrace or collapsed outwash.

In addition to the slumping and sliding of material that occurs on the vegetated part of the kame, there is re-arrangement of material on the unvegetated slopes by the action of running water. Springs emanating from within and beneath the ice carry debris that forms alluvial fans on the slopes of the collapsed part of the terrace. These streams also tend to undermine the loose gravel, causing further collapse and mixing of the deposit.

Debris flows are another mechanism in the formation of kames. The unvegetated slopes where the ice is closest to the surface may give way and slide into a gully. Then or several days later when sufficient moisture has accumulated in the gravel at the top of the gully, the mass of gravel becomes quick and flows down the gully (Fig. 3). Continued melting of the buried ice in this part of the terrace forms kettle holes in the debris flows and in the alluvial fans.

Still another factor in the movement of material in the collapsing kame terrace is the socalled stagnant-ice burst described previously. In Adams Inlet the stagnant-ice burst is apparently responsible for forming or enlarging gullies in the side of the kame and transport of debris away from the kame terrace. How often this process occurs is not known. The winter freeze may be enough to seal the outer parts of the kame that previously were open channels. In the spring, melt water and run-off from the mountain may be trapped in the stagnant ice and the whole process may recur. It may also be a unique occurrence that will not be repeated at the kames in Adams Inlet. The importance of stagnant-ice bursts as factors in reshaping ice-contact deposits is not known, for none are reported in the literature.

\section{Soll Temperature Variations in the Kame Terrage}

Soil temperatures were measured during the second summer using a YSI Tele-thermometer model $42 \mathrm{SC}$. This model is readable to $\pm 0.2^{\circ} \mathrm{C}$ in the range of operation and is accurate to $\pm 0.5^{\circ} \mathrm{C}$. Comparison with a standardized thermometer in an ice-water bath gave readings ranging from 0.1 to $0.2^{\circ} \mathrm{C}$ for the six thermistors. 
Four thermistors were set near the top of the kame terrace at depths of $0.5,0.9$, I.I and I. $3 \mathrm{~m}$ as shown in Figure 6, and two thermistors were set at depths of 0.8 and $0.55 \mathrm{~m}$ (Fig. 6), on the west and east flanks respectively of an unvegetated kame near the bottom of the collapsing north slope. Thermistor readings were taken once daily between 19.00 and $2 \mathrm{I} .30 \mathrm{~h}$. These results, including the cloudiness and precipitation determinations, are given in Figure 7 .

The results of the temperatures for the thermistors on top of the terrace indicate that the most significant temperature rise occurs during heavy rain. This is best illustrated by the readings for 8 August (Fig. 7) for thermistors on top of the terrace. Between 07.00 and $2 \mathrm{I}$.ooh on 8 August, $2.13 \mathrm{~cm}$ of rain were recorded. A rise in temperature of $2^{\circ} \mathrm{C}$ at $0.5 \mathrm{~m}$ in the kame between the evening readings of 7 and 8 August was noted. Even at $1.3 \mathrm{~m}$ depth a slight increase in the temperature was recorded. Although the maximum increase in temperature was recorded at the highest thermistor on the evening of 8 August, the maximum was not noted at the lower thermistors until the evening of 9 August. By 13 August most of the

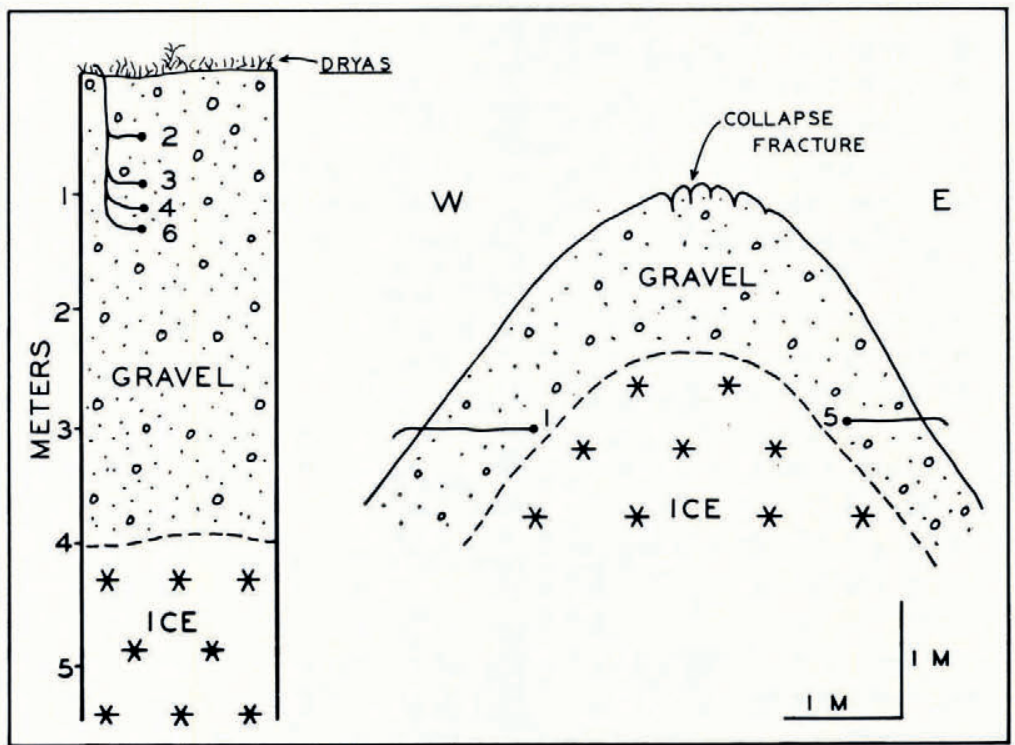

Fig. 6. Sketch of thermistor locations on top of the kame terrace (left) and on a kame on the north slope of the kame terrace (right)

thermistors indicated temperatures about the same as before the heavy rain. The temperature in the upper part of the kame continued to decrease and fell lower than it had been before the rain until it reached a minimum on 14 August. By then the gravel at the surface, without continued high input of solar energy on the overcast and foggy days that prevailed, could no longer act as an effective heat source for the percolating water. Thus the temperature of the upper layers continued to fall. The total amount of precipitation for the period from $2 \mathrm{I} . \mathrm{Oo} \mathrm{h}$ on 7 August to $07.00 \mathrm{~h}$ on I I August was $8.25 \mathrm{~cm}$. The greatest input of heat into the kame occurred on 8 August when the rain was the heaviest and the upper layers of the gravel warmest. The temperature impulse caused by the heavy rains attenuated as it traveled into the kame (Fig. 7). Temperature data following other heavy rains are not available.

The effectiveness of rain as an agent of ablation on bare glacier ice is not completely known (Marcus, I964). Part of the increase in ablation of a glacier during rain is due to the kinetic energy produced by the rain drops; most of the energy comes from the rain that may be warmer than the surrounding air at the surface of the ice. Although many studies suggest 
that the effect may be negligible, Marangunic (unpublished) noted a two- to three-fold increase in ablation on the debris-free glacier surface during periods of heavy rain.

In the climate of Adams Inlet, solar radiation is ineffective alone in raising the temperature at depth in the soil. It is through a combination of a sunny period, in which the surface temperatures are raised, followed by heavy rains that transfer surface heat to the lower part of the kame, that the temperature at depth is raised. Near the surface, daily fluctuations in temperature reflect the changes in solar radiation. This is particularly evident in the case of the thermistors buried at $\mathrm{IO}$ and $12 \mathrm{~cm}$ in the unvegetated part of the kame (Fig. 7).

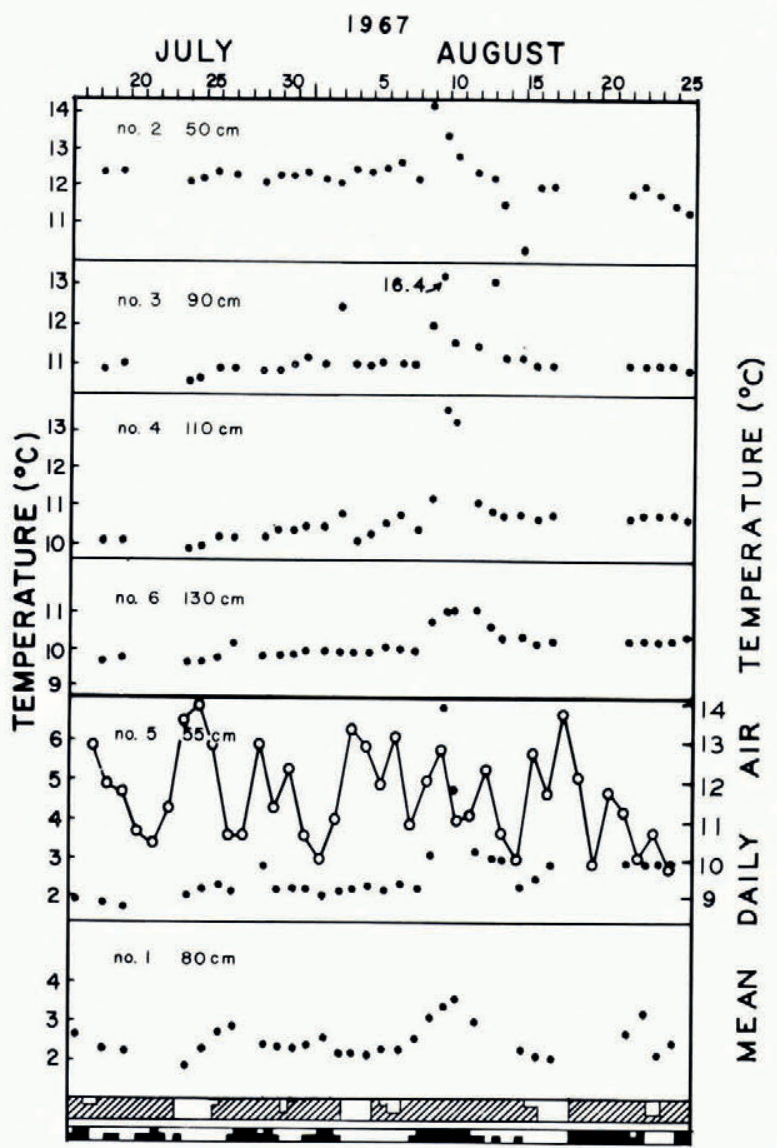

Fig. 7. Daily soil temperatures in the kame terrace. Thermistors 2, 3, 4 and 6 were in the top of the terrace (Fig. 6) with No. 6 thermistor $2.7 \mathrm{~m}$ above the ice. Thermistors $I$ and 5 were on the west and east sides, respectively, of a kame on the unvegetated slope. Cloudiness given in the upper set of shaded blocks: solid is overcast, 2/3 shaded is mostly cloudy, $1 / 3$ shaded is partly cloudy and unshaded is clear. Precipitation code: total shaded is $>0.2 \mathrm{~cm}, \mathrm{I} / 2$ shaded is $<0.2 \mathrm{~cm}$.

Hourly readings were taken for $29 \mathrm{~h}$ on all thermistors on 30 and $3 \mathrm{I}$ July (Fig. 8). Both of these days were overcast with only $\mathrm{I}$ h of sun on $3^{0} \mathrm{July}$. $3^{\mathrm{I}} \mathrm{July}$ was foggy with drizzle and a total of $0.03 \mathrm{~cm}$ of precipitation was recorded. Over this period most of the thermistors, including those at shallow depth, showed only $0.2-0.7$ deg change. This is to be expected because of the minor change in solar radiation and little precipitation during this period. Two thermistors showed increased temperatures over a $5 \mathrm{~h}$ period between 07.00 and $\mathrm{I} 2.00 \mathrm{~h}$. At $90 \mathrm{~cm}$ a rise of $0.7 \mathrm{deg}$ was recorded and at $\mathrm{I} I 0 \mathrm{~cm}$ a rise of $\mathrm{I} .4 \mathrm{deg}$ was noted. These changes 
do not appear to be related to fluctuations in radiation or precipitation and were not recorded in the levels below or above. These temperature changes might be due to phase changes. Water vapor might be condensing in this layer and thus supplying heat to this part of the kame. Horizontal mass transfer in this layer could be the source of the moisture.

Over the $39 \mathrm{~d}$ observation period in 1967 the temperature at $1.3 \mathrm{~m}$ in the kame terrace rose $\mathrm{r} .4 \mathrm{deg}$. This increase in temperature is part of an annual sinusoidal heat wave that penetrates into the kame. It reaches a maximum in late summer and then decreases over the winter; the depth of frost in this area is unknown. Other minor fluctuations in the $39 \mathrm{~d}$ record may also be due to percolating precipitation; however, the effectiveness of slight rainfalls seems to be minor.

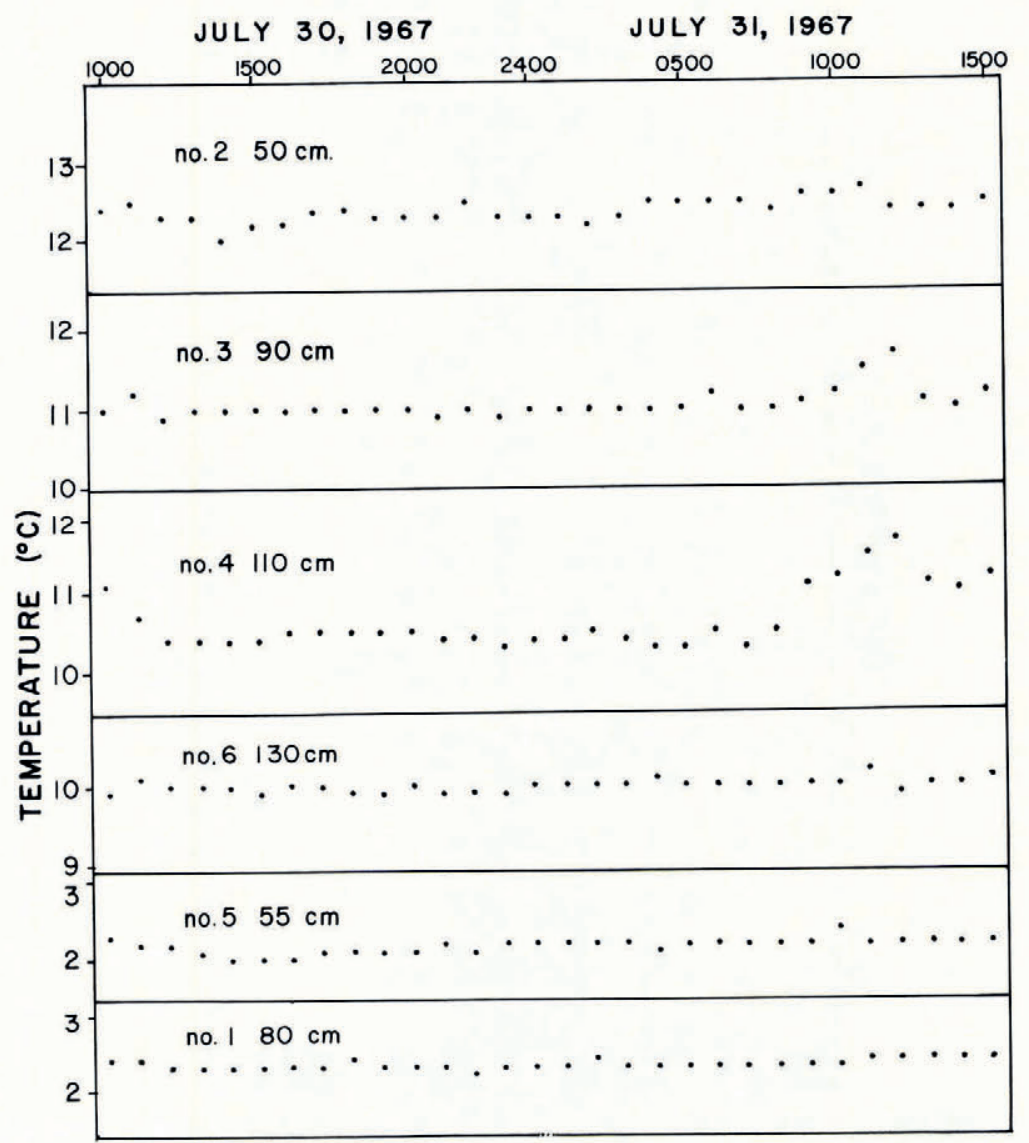

Fig. 8. Hourly soil temperatures in the top of the kame terrace and in the side of the kame terrace (see Figure 6 for location of thermistors).

\section{Rate of collapse}

The rate of melting of the stagnant ice determines the rate of collapse of the kame terrace. An estimate of the rate of transfer of heat to the ice by conduction can be obtained by the temperature-gradient method (Staley and Gerhardt, 1958). Heat may also be transferred by percolation of rain water, change of state, radiation and convection within the gravel. No estimate of the amount of heat transferred to the ice by these methods is included here. As seen by the increase in temperature during rainy periods, the percolation factor may be very 
important in this climate. Basal melting by terrestrial heat flow also reduces the volume of the buried ice. For this area the supply of heat is about $6.49 \times 10^{-6} \mathrm{~J} \mathrm{~cm}^{-2} \mathrm{~s}^{-1}$ (Lee and MacDonald, 1963). This would be sufficient to melt $0.6 \mathrm{I} \mathrm{cm}$ year ${ }^{-1}$.

The heat flow by conduction to the ice can be determined by the formula

$$
S=\lambda \frac{\mathrm{d} T}{\mathrm{~d} Z}
$$

where $S$ is the soil heat-flux, $\lambda$ is the thermal conductivity, and $\mathrm{d} T / \mathrm{d} Z$ is the temperature gradient with depth. For the vegetated area on top of the kame terrace (Figs. 2 and 6), the lowest thermistor (No. 6) is $2.7 \mathrm{~m}$ above the ice. During the period of observation the temperature increased from $9.7^{\circ} \mathrm{C}$ to $10.4^{\circ} \mathrm{C}$ not including the pulses caused by percolation (Fig. 7). Taking $10.0^{\circ} \mathrm{C}$ as an average during this interval, the writer determined the temperature gradient, from a depth of $1.3 \mathrm{~m}$ to the surface of the ice, to be $0.037 \mathrm{deg} \mathrm{cm}^{-1}$.

An estimate of the thermal conductivity of the gravel has been obtained by comparison of moisture contents and grain-size distributions for two samples with values for similar material given in the literature. The grain-size distribution and conductivities for several unconsolidated materials are given in Table I along with the characteristics of the two samples $\left(67^{-23}-1,67^{-23}-2\right)$ from the unvegetated part of the kame terrace.

Table I. Grain-size Analyses and Some Thermal Conductivities for Selected Unconsolidated Materials

\begin{tabular}{|c|c|c|c|c|c|}
\hline Sample & $>2.0 \mathrm{~mm}$ & $\begin{array}{c}\text { Grain-size analysi } \\
\text { weight } \% \\
2.0 \text { to } 0.05 \mathrm{~mm}\end{array}$ & $<0.05 \mathrm{~mm}$ & $\begin{array}{c}\text { Moisture } \\
\text { weight } \%\end{array}$ & $\begin{array}{c}\text { Conductivity } \\
\mathrm{J} \mathrm{cm}^{-1} \mathrm{~s}^{-1} \operatorname{deg}^{-1}\end{array}$ \\
\hline Gravel* & 60.0 & 32.5 & $7 \cdot 5$ & 5.0 & $1.25 \times 10^{-2}$ \\
\hline Chena gravel $\dagger$ & 80.0 & $19 \cdot 4$ & 0.6 & 3.0 & $1.57 \times 10^{-2} \ddagger$ \\
\hline Fairbanks sand $\dagger$ & 27.5 & 70.0 & 2.5 & 5.0 & $1.48 \times 10^{-2} \div$ \\
\hline $67-23^{-1}$ & 34.0 & 62.0 & 4.0 & 5.4 & - \\
\hline $67-23-2$ & 34.8 & 60.0 & 5.2 & $5 \cdot 2$ & - \\
\hline
\end{tabular}

* Wechsler (ig66).

$\dagger$ Kersten (1966, unpublished).

¥ Average for several densities.

According to Kersten (I966), the conductivity of a soil varies with the grain-size, moisture content, density, composition, temperature and the state of the moisture (solid or liquid). Texture and moisture content are probably the most important, and from a comparison of the values in Table I an estimated conductivity of $\mathrm{I} .5 \times \mathrm{IO}^{-2} \mathrm{~J} \mathrm{~cm}^{-1} \mathrm{~s}^{-1} \mathrm{deg}^{-1}$ for the gravel in the kame terrace is reasonable.

From the gradient and assumed conductivity value for this gravel the supply of heat to the surface of the stagnant ice block during July and August averages about $5.5 \times \mathrm{IO}^{-4}$ $\mathrm{J} \mathrm{cm}^{-2} \mathrm{~s}^{-1}$. Assuming that $0.90 \mathrm{~g}$ of ice occupy $\mathrm{I} \mathrm{cm}{ }^{3}$ and that the heat of fusion of water is $335 \mathrm{~J} \mathrm{~g}^{-1}$, then during these 2 months approximately $9.6 \mathrm{~cm}$ of ice would melt from the upper surface of the stagnant ice block. This rate of melting probably decreases during the spring and fall, and melting ceases during the winter. If we assume that this rate lasts for 5 months of the year where the debris cover is about $4 \mathrm{~m}$ thick, the rate of surface lowering of the ice due to ablation by conduction would be about $24 \mathrm{~cm}_{\text {year }}^{-1}$.

The rate of melting of ice beneath the unvegetated part of the kame, where the gravel cover was only $0.5^{-0.8} \mathrm{~m}$ thick, averages about $0.8 \mathrm{~cm} \mathrm{~d}^{-1}$ during July and August, and occasionally it may be as high as $1.0 \mathrm{~cm} \mathrm{~d}^{-1}$ during rainy periods. Thus the back-wasting of the thinly covered (at times uncovered, as in Figure 3) part of the kame terrace is faster than the downwasting of the upper vegetated and more thickly covered area.

If it is assumed that the average annual ablation of the ice is about $24 \mathrm{~cm}$, and future changes in the vegetated surface that might affect the ablation rate are neglected, then the 
$35 \mathrm{~m}$ thick ice block would melt in 146 years. The actual length of time that the ice remains will in fact be much less because of factors not included in the estimation. Back-wasting of the kame terrace sides, where the ablation rate is much higher, will also contribute to the much earlier removal of the ice. This ice will melt more quickly than those buried ice blocks that are completely surrounded by unconsolidated material.

\section{Summary}

A collapsing kame terrace, consisting of $4 \mathrm{~m}$ of sandy, coarse cobbly gravel with a vegetated surface of Dryas and some alder and poplar, was studied to determine the mode and rate of collapse. The hummocky terrace with depressions as deep as $5 \mathrm{~m}$ is underlain by ice estimated to be $35 \mathrm{~m}$ thick.

Re-arrangement of the debris cover on the ice is seen to take place by: slumping and sliding of debris to low areas, melt-water erosion with deposition in alluvial fans on the sides of the terrace, debris flows in gullies, and the stagnant-ice burst phenomenon in which water under pressure breaks through an ice dam causing much erosion of the surrounding gravel.

Temperatures (at several depths) in the gravel on top of the terrace indicate that the flow of heat by conduction to the surface of the buried ice may be as much as $5.5 \times 1 \mathrm{IO}^{-4} \mathrm{~J} \mathrm{~cm}^{-2} \mathrm{~s}^{-1}$ during the months of July and August. This rate of heat flow is sufficient to melt $9.6 \mathrm{~cm}$ of ice from the buried ice block during this period. Assuming this rate for 5 months of the year (although the heat flow is lower at the beginning and end of the summer, the ablation season may be longer than 5 months at lower rates), the lowering of the ice surface may be as much as $24 \mathrm{~cm}$ year $^{-1}$. As expected, this is much lower than the ablation rate for the debris-free stagnant ice of Adams Inlet Glacier that ablated at the average rate of $7.9 \mathrm{~m} \mathrm{year}^{-1}$ between I890 and I94I. The estimated length of time for survival of ice in this debris-covered kame terrace, that is thinly debris-covered and at times uncovered, is less than other ice blocks that are completely surrounded by unconsolidated material.

\section{Acknowledgements}

Support for this research was supplied by a National Science Foundation grant (GA-403) awarded to The Ohio State University Research Foundation and administered by the Institute of Polar Studies. Logistic support was provided by the National Park Service. W. C. Lefler, T. R. Merrell III and S. Goldthwait assisted in the field investigations. G. Dewart, M. Hoyer, J. Lindsay, J. Mercer and J. Splettstoesser read the manuscript and made valuable suggestions on its improvement.

MS. received 12 February 1969

\section{REFERENCES}

Charlesworth, J. K. 1957. The Quaternary era, with special reference to its glaciation. London, Edward Arnold Ltd. 2 vols.

Clayton, L. 1964. Karst topography on stagnant glaciers. Fournal of Glaciology, Vol. 5, No. 37, p. 107-12.

Embleton, C., and King, C. A. M. 1968. Glacial and periglacial geomorphology. London, Edward Arnold Ltd.

Field, W. O., jr. 1947. Glacier recession in Muir Inlet, Glacier Bay, Alaska. Geographical Review, Vol. 37, No. 3, p. $369-99$.

Flint, R. F. [1957.] Glacial and Pleistocene geology. New York, John Wiley and Sons, Inc.

Goldthwait, R. P., and others. I 966 . Soil development and ecological succession in a deglaciated area of Muir Inlet, southeast Alaska, by R. P. Goldthwait, F. Loewe, F. C. Ugolini, H. F. Decker, D. M. DeLong, M. B. Trautman, E. E. Good, T. R. Merrell III, and E. D. Rudolph. Ohio State University. Institute of Polar Studies.

Report No. 20.
Kersten, M. S. 1966. Thermal properties of frozen ground. (In U.S. National Research Council. Building Research Advisory Board. Proceedings of an international conference on permafrost. Washington, D.C., p. $30 \mathrm{I}-\mathrm{O} 5$. ([U.S.] National Academy of Sciences-National Research Council Publication 1287.)) 
Kersten, M. S. Unpublished. Final report, laboratory research for the determination of the thermal properties of soils. [Written for U.S. Army Corps of Engineers, 1949.]

Lee, W. H. K., and MacDonald, G. J. F. 1963 . The global variation of terrestrial heat flow. Journal of Geophysical Research, Vol. 68, No. 24, p. $6481-92$.

Lister, H. I953. Report on glaciology at Breiðamerkurjökull I951. Jökull, [Vol. I], Ár 3, p. 23-31.

Marangunic, C. Unpublished. Effects of a landslide on Sherman Glacier, Alaska. [Ph.D. thesis, Ohio State University, 1968.]

Marcus, M. G. I964. Climate-glacier studies in the Juneau Ice Field region, Alaska. University of Chicago. Dept. of Geography. Research Paper No. 88.

Reid, H. F. 1896 . Glacier Bay and its glaciers. U.S. Geological Survey. I6th Annual Report, [for the year] 1894-95, Pt. I, p. 415-6I.

Sharp, R. P. 1947. The Wolf Creek glaciers, St. Elias Range, Yukon Territory. Geographical Review, Vol. 37, No. I, p. $26-52$.

Sharp, R. P. I949. Studies of superglacial debris on valley glaciers. American fournal of Science, Vol. 247, No. 5 p. $289-315$.

Staley, R. C., and Gerhardt, J. R. 1958. Soil heat flux measurements. (In Lettau, H. H., and Davidson, B., ed. Exploring the atmosphere's first mile. New York, Pergamon Press, p. 58-63.)

Swithinbank, C. W. M. 1950. The origin of dirt cones on glaciers. Fournal of Glaciology, Vol. I, No. 8, p. $46 \mathrm{I}-65$.

Wechsler, A. E. 1966 . Development of thermal conductivity probes for soils and insulations. U.S. Cold Regions Research and Engineering Laboratory. Technical Report 182. 